Analisis Pengaruh Rasio CAR, NPF, BOPO, ROA, dan FDR

Analisis Pengaruh Rasio CAR, NPF, BOPO, ROA, dan FDR terhadap Tingkat Kesehatan Bank Umum Syariah di Indonesia

\author{
Eva Ratna Festiani \\ Accounting Department, Faculty of Economy \\ Maulana Malik Ibrahim, State Islamic University of Malang, \\ Indonesia
}

This study aims to analyze the influence of the ratio of Capital Adequacy Ratio, NPF, ROA, ROA and FDR against Islamic commercial bank soundness. This research is a quantitative study using secondary data obtained from the annual reports in Indonesian Islamic Banks published by Bank Indonesia and the data bank health ratings obtained from annual reports of Islamic Banks and bank info Research. Thus, the sample used by 11 Islamic Banks. This study uses a model of Ordinal Logit Regression analysis to analyze the effect of the ratio of Capital Adequacy Ratio, NPF, ROA, ROA and FDR. The results showed that the Non Performing Financing (NPF) Operating Income and Operating Expenses significant effect on the health of banks with significant value and NPF 0,040 0,020 Operating Expenses Operating Income. While the Capital Adequacy Ratio, ROA, FDR did not have a significant influence on the health of banks, due to the significant value of each variable is more than 0.05 ( $p>$ $5 \%)$.

Keywords: Capital Adequacy Ratio, Non-Performing Financing, Operating Expenses Operating Income, Return on Assets, Financing to Deposits Ratio, Bank Soundness

\title{
PENDAHULUAN
}

Dalam persaingan global, perekonomian suatu negara mempunyai peranan penting bagi semua aspek kehidupan. Perbankan berkembang pesat setelah terjadi deregulasi di bidang keuangan dan moneter pada tahun 1983. Deregulasi tersebut telah mengakibatkan kebutuhan dana yang banyak mendorong tumbuhnya produk dan jumlah cabang yang pada gilirannya semakin banyak masyarakat yang membutuhkan jasa perbankan (Taswan,2006).

Baru- baru ini, sistem keuangan syariah telah menarik perhatian pasar keuangan konvensional. Menurut beberapa perkiraan, lebih dari 250 lembaga keuangan di lebih dari 45 negara mempraktikkan suatu bentuk dari sistem keuangan syariah. Industri perbankan syariah ini berkembang pada tingkat yang 
lebih besar dari $15 \%$ per tahun selama lima tahun terakhir. Omzet tahunan pasar saat ini diperkirakan sebesar \$350 miliar, dibandingkan dengan hanya $\$ 5$ miliar pada tahun 1985. Sejak munculnya bank syariah pada awal 1970, banyak penelitian telah dilakukan dengan terfokus pada kelangsungan hidup, desain dan operasi dari lembaga keuangan " penerima - simpanan" yang mempunyai fungsi utama berdasarkan kemitraan laba- rugi dan bukan pembayaran atau penerimaan bunga, suatu elemen yang dilarang dalam Islam (Iqbal, 2011).

Pada tahun 2008, perekonomian di Indonesia mengalami krisis keuangan yang diakibatkan oleh faktor- faktor yang terjadi di luar negeri. Dampak dari krisis tersebut, pertumbuhan ekonomi dunia melambat dan volume perdagangan global pada tahun 2009 ikut merosot tajam. Dampak lain yang terjadi di Indonesia adalah banyaknya industri besar yang terancam bangkrut, terjadinya penurunan kapasitas produksi dan terjadinya lonjakan jumlah pengangguran dunia. Bagi negara - negara berkembang, situasi seperti ini dapat merusak fundamental perekonomian dan memicu terjadinya krisis ekonomi. Terjadinya krisis inilah, maka banyak tingkat kesehatan perusahaan banyak mengalami kebangkrutan (Septian, 2013).

Kemungkinan datangnya krisis global adalah disebabkan oleh gagalnya perbankan nasional dalam memprediksi secara akurat terhadap pergerakan naik turunnya nilai mata uang pasar, otoritas moneter yang tidak mampu mengatasi pinjaman luar negeri yang dilakukan oleh kalangan swasta dalam negeri sehingga semakin banyak pinjaman yang jatuh tempo tidak mampu ditutupi oleh cadangan devisa. Perbaikan ekonomi nasional harus dilakukan serentak dengan sistem perbankan nasional yang kuat sekaligus sehat.

Pada saat krisis moneter ini, Bank Indonesia lebih gencar melakukan restrukturisasi perbankan yag diharapkan dapat memunculkan struktur perbankan yang lebih kuat, efektif, efisien dan sehat. Pengalaman krisis keuangan ini telah membawa dunia perbankan Indonesia mampu bertahan dalam krisis tahun 2008. Seperti halnya yang terjadi pada PT. Bank Muamalat Syariah, bank ini mampu bertahan dengan predikat bank yang dikatakan sehat pada periode 2007 - 2009. Aspek permodalan pada bank ini menunjukkan angka $15,51 \%$ sampai $51,30 \%$, aspek kualitas aktiva menunjukkan angka nol hingga 10,35\%, aspek rentabilitas menunjukkan angka 1,215\% untuk ROA dan 93,52\% untuk BOPO, 
aspek likuiditas menunjukkan angka dibawah $94,75 \%$, sedangkan aspek manajemen dikatakan berpredikat sehat (Lestari dan Rahyuda,2011)

Penilaian kesehatan bank dilakukan setiap periode. Dalam setiap periode penilaian ditentukan suatu bank apakah bank itu sehat ataupun tidak. Bagi bank yang sudah dinilai sebelumnya dapat pula dinilai apakah ada peningkatan atau penurunan kesehatannya. Bagi bank yang menurut penilaian sehat atau kesehatannya terus meningkat tidak jadi masalah, karena itulah yang diharapkan dan supaya tetap dipertahankan. Akan tetapi bagi bank yang terus menerus tidak sehat, maka harus mendapat pengarahan atau bahkan sanksi sesuai dengan peraturan yang berlaku.

Tingkat kesehatan bank merupakan suatu sistem peringatan dini atas kinerja saat ini dan prospeknya di masa mendatang. Tingkat kesehatan bank sangat menetukan kualitas dan keseimbangan sistem keuangan nasional. Beberapa cara untuk mengukur tingkat kesehatan didasarkan pada SK BI Nomor 30/3/UPBB tanggal 1997 perihal tata cara penilaian tingkat kesehatan dapat dilakukan dengan analisis CAMEL. Analisis CAMEL terdiri dari Capital (permodalan), Asset Quality (kualitas aktiva), Management (manajemen), Earning (rentabilitas) dan Liquidity (likuiditas).

Ada beberapa penelitian yang terkait dengan tingkat kesehatan bank adalah penelitian Almilia dan Herdiningtyas (2005), menyimpulkan bahwa hanya BOPO dan CAR yang berpengaruh signifikan terhadap kesehatan bank. Fitri Ruwaida (2011), penelitian ini menyimpulkan bahwa kelima faktor tersebut berpengaruh positif terhadap tingkat kesehatan bank. Utama dan Mahadewi (2012), menyimpulkan bahwa 1 Bank berpredikat sehat, 1 Bank bepredikat cukup sehat dan yang lainnya tidak sehat. Jeremiah Kevin Dennis Jacob (2013), menunjukkan hasil bahwa Bank Mandiri, Bank BRI, Bank BNI dikatakan sangat sehat, sedangkan Bank BTN dikatakan sehat.

Pada penelitian Almilia dan Herdiningtyas (2005) menghasilkan BOPO dan CAR berpengaruh secara signifikan terhadap tingkat kesehatan bank. Namun, pada penelitian Fitri Ruwaida (2011) menyimpulkan kelima faktor CAMEL memiliki pengaruh positif terhadap tingkat kesehatan bank. Berdasarkan hasil penelitian tersebut dan beberapa masalah perbankan yang 
timbul di Indonesia, peneliti tertarik untuk meneliti kembali terkait tingkat kesehatan bank.

Dari alasan- alasan peneliti kemukakan sebelumnya dan untuk melihat sejauh mana tingkat kesehatan pada bank syariah di Indonesia, maka perlunya Analisis Pengaruh Rasio CAR, NPF, BOPO, ROA, dan FDR Terhadap Tingkat Kesehatan Bank Umum Syariah Di Indonesia.

\section{TINJAUAN PUSTAKA}

\section{Tingkat Kesehatan Bank}

Tingkat kesehatan bank merupakan hasil penilaian kualitatif atas berbagai aspek uang mempengaruhi terhadap kondisi atau kinerja suatu bank melalui penilaian faktor permodalan, kualitas aset, manajemen, rentabilitas dan likuiditas. Penilaian terhadap faktor- faktor tersebut dilakukan melalui penilaian kuantitatif dan atau kualitatif setelah mempertimbangkan unsur judgement yang didasarkan atas materialitas dan signifikansi dari faktor- faktor penilaian serta pengaruh dari faktor lainnya seperti kondisi industri perbankan dan perekonomian nasional (Taswan,2006).

Riyadi (2006) menyatakan tingkat kesehatan suatu bank menjadi salah satu tolok ukur kinerja keuangan bank yang sangat penting. Terdapat beberapa pihak yang sangat membutuhkan hasil penilaian tingkat kesehatan bank yaitu : pengelolaan Bank, masyarakat pengguna jasa bank, Bank Indonesia, dan Counterparty Bank (adanya hubungan koresponden).Penilaian kesehatan bank oleh bank sentral dengan melakukan penilaian terhadap aspek- aspek yang telah ditetapkan.

Menurut Peraturan Bank Indonesia No. 9/1/PBI/2007 tentang Sistem Penilaian Tingkat Kesehatan Bank Umum Berdasarkan Prinsip Syariah, tingkat kesehatan bank adalah hasil penilaian atas berbagai aspek yang berpengaruh terhadap kondisi atau kinerja suatu Bank atau UUS melalui:

1. Penilaian kuantitatif dan penilaian kualitatif terhadap faktorfaktor permodalan, kualitas aset, rentabilitas, likuiditas, sesntivitas terhadap risiko pasar, dan

2. Penilaian kualitatif terhadap faktor manajemen.

\section{Capital Adequacy Ratio (CAR)}

CAR merupakan salah satu indikator kesehatan permodalan bank. Penilaian permodalan merupakan penilaian 
terhadap kecukupan modal bank untuk mencover eksposur risiko saat ini dan mengantisipasi eksposur risiko di masa mendatang. CAR memperlihatkan seberapa besar jumlah seluruh aktiva bank yang mengandung risiko ikut dibiayai dari modal sendiri disamping memperoleh dana- dana dari sumber- sumber diluar bank (Almilia dan Herdiningtyas, 2005).

Berdasarkan Surat Edaran Bank Indonesia No.9/24/DPbS tahun 2007 tujuan rasio CAR adalah untuk mengukur kecukupan modal bank dalam menyerap kerugian dan pemenuhan ketentuan CAR yang berlaku. Bank wajib memelihara rasio CAR. Penilaian faktor permodalan menggunakan CAR digunakan untuk mengetahui kecukupan modal bank dalam mendukung kegiatan operasional bank. CAR ini merupakan rasio utama yang digunakan untuk melakukan analisis atas penilaian tingkat kesehatan bank berdasarkan prinsip syariah (Lampiran1, Surat Edaran Bank Indonesia No.9/24/DPbS tahun 2007).

Modal dalam perhitungan CAR bagi bank terdiri dari modal inti dan modal pelengkap. Modal inti terdiri atas modal disetor, modal sumbangan, cadangan- cadangan yang dibentuk dari laba setelah pajak dan laba yang diperoleh setelah diperhitungkan pajak. Modal pelengkap terdiri dari cadangancadangan yang dibentuk tidak berasal dari laba, modal pinjaman dan pinjaman subordinasi. ATMR dihitung dengan mengalikan nilai nominal dalam pos- pos aktiva dengan presentase bobot tertentu sesuai dengan ketentuan berlaku.

Modal dalam Islam yang diriwayatkan oleh Imam Malik secara mauquf dari Umar Bin Khaththab dam kitab (AlMuwaththa' 1/ 251 dalam Munir, 2007: 91), juga diriwayatkan oleh Baihaqi dengan sanad shahih, sedangkan Imam Syafi'i meriwayatkan secara mauquf dari Ibn Umar (Tuhfat Al- Ahwadli: 3/238 dalam Munir, 2007:91). Sedangkan yang marfu' diriwayatkan oleh al- Thabrani dalam al- Mu'jam al- Ausath dari riwayat Anas bin Malik, dengan sanad yang shahih menurut guru al- Haisamiy. (Lih Majma' al-Zawaid: 3/67 dalam Munir, 2007:91) Dalam hadist tersebut kita diperintahkan untuk memutar harta anak yatim dalam aktifitas produktif melalui cara perdagangan atau dalam bentuk investasi lainnya. Hal tersebut dimaksudkan agar harta anak yatim tersebut tidak berkurang karena zakat yang dikeluarkan darinya.

Adapun rumus dari rasio Capital Adequancy Ratio (CAR) sebagai berikut 
$\mathrm{CAR}=\frac{\text { Jumlah Modal ATMR }}{\mathrm{ATMR}} 100 \%$

Keterangan:

$\mathrm{CAR}=$ Capital Adequacy Ratio

ATMR $=$ Aktiva Tertimbang Menurut Risiko

\section{Non Performing Financing (NPF)}

Pada bank syariah istilah Non Performing Loan (NPL) diganti dengan Non Performing Finance (NPF) karena dalam syariah menggunakan prinsip pembiayaan. Rasio ini digunakan untuk menilai kualitas aset. Penilaian kualitas aktiva produktif adalah menilai jenis- jenis aktiva suatu bank agar sesuai dengan ketetapan Bank Indonesia, sehingga kemungkinan diterimanya kembali dana yang ditanam pada suatu investasi atau pembiayaan dapat diketahui. Tingkat kelangsungan usaha bank berkaitan erat dengan aktiva produktif yang dimillikinya, oleh karena itu manajemen bank dituntut untuk senantiasa dapat memantau dan menganalisa kualitas aktiva produktif yang dimiliki. Kualitas aktiva produktif menunjukkan kualitas aset sehubungan dengan risiko pembiayaan yang dihadapi akibat pemberian pembiayaan dan investasi dana bank. Aktiva produktif yang dinilai meliputi penanaman dana baik dalam rupiah maupun valuta asing, dalam bentuk pembiayaan dan surat berharga (Siamat, 2005).

Penilaian kualitas aset merupakan penilaian terhadap kondisi aset Bank atau UUS dan kecukupam manajemen risiko pembiayaan. Besarnya pembiayaan ini diukur dengan Non Performing Financing (NPF). NPF merupakan indikator penilaian tingkat kesehatan bank (Surat Edaran Bank Indonesia No.9/24/DPbS tahun 2007). Adapun rumus dari Non performing Financing (NPF) adalah

$\mathrm{NPF}=\stackrel{\text { Pembiayaan total }}{\text { Pembiayaan }} \times 100$

Pembiayaan

Beban Operasional dengan Pendapatan Operasional (BOPO)

Rasio yang sering disebut rasio efisiensi ini digunakan untuk mengukur kemampuan manajemen bank dalam mengendalikan biaya operasional terhadap pendapatan 
operasional (Almilia dan Herdiningtyas, 2005). Berdasarkan Surat Edaran Bank Indonesia No.9/24/DPbS tahun 2007, tujuan dari rasio ini adalah untuk mengukur kegiatan operasional bank syariah.

Biaya operasi merupakan biaya yang dikeluarkan oleh bank dalam rangka menjalankan aktivitas usaha utamanya seperti biaya pemasaran, biaya tenaga kerja dan biaya operasional lainnya. Sedangkan pendapatan operasional merupakan pendapatan utama bank yaitu pendapatan yang diperoleh dari penempatan dana dalam bentuk pembiayaan dan pendapatan operasional lainnya. (Septian, 2013). Adapun rasio Beban Operasional dengan Pendapatan Operasional (BOPO) adalah sebagai berikut:

$\mathrm{BOPO}=\underline{\text { biaya operasional }} x 100 \%$ pendapatan operasional

\section{Return on Asset (ROA)}

Rasio ini merupakan salah satu dari rasio yang digunakan untuk menilai aspek earning. Rasio ini digunakan untuk mengukur kemampuan manajemen bank dalam memperoleh keuntungan (laba sebelum pajak) yang dihasilkan dari rata- rata total aset bank yang bersangkutan (Almilia dan Herdiningtyas, 2005). Berdasarkan Surat Edaran Bank Indonesia No.9/24/DPbS tahun 2007, tujuan dari rasio ROA adalah untuk mengukur keberhasilan manajemen dalam menghasilkan laba dengan keseluruhan aktiva yang tersedia dalam bank. Adapun rumus dari rasio ROA adalah sebagai berikut:

\section{ROA $=\underline{\text { Laba Sebelum Paja }} 100 \%$ Total Aset}

\section{Financing to Deposits Ratio (FDR)}

Rasio ini digunakan untuk menilai faktor likuiditas. Penilaian faktor ini bertujuan untuk mengukur kemampuan bank dalam memenuhi kewajiban jangka pendek. Pengelolaan likuiditas merupakan masalah yang cukup kompleks dalam kegiatan operasi bank. Sulitnya pengelolaan likuiditas tersebut disebabkan dana yang dikelola bank sebagian besar adalah dana masyarakat yang sifatnya jangka pendek dan dapat ditarik sewaktu- waktu. Oleh karena itu, bank harus memperhatikan seakuratmungkin kebutuhan likuditas untuk suatu jangka waktu tertentu itu (Siamat, 2005). 
Pada lembaga perbankan persoalan likuiditas merupakan persoalan pada dua sisi pada neraca bank. Sebagai lembaga kepercayaan bank harus sanggup menjalankan fungsinya sebagai penghimpun dana dan sebagai penyalur dana untuk memperoleh profit yang wajar. Pada sisi passiva, bank harus mampu memenuhi kewajiban kepada nasabah setiap ada penarikan simpanan nasabah, pada sisi aktiva bank harus menyanggupi pencairan kredit yang telah diperjanjikan (Muhammad, 2011).

Adapun rumus untuk rasio FDR adalah sebagai berikut:

FDR $=$ Total Pembiayaan $X 100 \%$

Total Dana Pihak Ketiga

\section{METODOLOGI PENELITIAN}

Penelitian dilakukan dengan menggunakan metode kuantitatif. Penelitian metode kuantitatif digunakan sebagai pendekatan ilmiah terhadap pengambilan keputusan manajerial dan ekonomi. Metode kuantitatif yaitu metode yang menekankan pada pengujian teori melalui pengukuran variabel- variable penelitian dengan angka- angka dan melakukan analisis data dengan prosedur statistik.

Penelitian ini menggunakan data sekunder yang diperoleh dari laporan keuangan tahunan Bank Umum Syariah di Indonesia yang melaporkan laporan keuangan tahunannya di Bank Indonesia pada periode 2010- 2013. Ruang lingkup dalam penelitian ini dilakukan di Bank Umum Syariah di Indonesia dengan mengakses website Bank Indonesia yaitu www.bi.go.id.

\section{HASIL PENELITIAN}

\section{Pengaruh Financing to Deposito Ratio (FDR) Terhadap Tingkat} Kesehatan Bank

Hasil pengujian secara Ordinal Logistic Regression pada tabel 4.8 antara Financing to Deposito Ratio (FDR) dengan tingkat kesehatan bank menunjukkan nilai koefisien sebesar -0,025. FDR dengan nilai koefisien bertanda negatif mengindikasikan bahwa FDR memiliki hubungan yang berlawanan arah dengan tingkat kesehatan bank. Sedangkan signifikansi FDR sebesar 0,084 ( $p>5 \%)$ menunjukkan bahwa FDR tidak memiliki pengaruh yang signifikan terhadap tingkat kesehatan bank. Secara ringkas nilai koefisien dan nilai signifikan masing- masing variabel dapat ditampilkan pada tabel berikut ini:

Tabel Financing to Deposit Ratio 
Analisis Pengaruh Rasio CAR, NPF, BOPO, ROA, dan FDR

\begin{tabular}{|l|l|l|l|}
\hline No & Variabel & $\begin{array}{l}\text { Nilai } \\
\text { Koefisien }\end{array}$ & $\begin{array}{l}\text { Nilai } \\
\text { Signifikansi }\end{array}$ \\
\hline 1 & Capital Adequacy Ratio (CAR) & $-0,014$ & 0,334 \\
\hline 2 & Non Performing Financing (NPF) & 0,619 & 0,040 \\
\hline 3 & $\begin{array}{l}\text { Beban Operasional dan Pendapatan } \\
\text { Operasional (BOPO) }\end{array}$ & $-0,105$ & 0,020 \\
\hline 4 & Return on Assets (ROA) & $-0,468$ & 0,080 \\
\hline 5 & Financing to Deposit Ratio (FDR) & $-0,025$ & 0,084 \\
\hline
\end{tabular}

Sumber: Data Diolah Peneliti, 2014

\section{Pengaruh Capital Adequacy Ratio (CAR) Terhadap Tingkat Kesehatan Bank}

Hipotesis 1 : CAR berpengaruh terhadap tingkat kesehatan bank

Berdasarkan hasil pengujian dengan Ordinal Logistic Regression yang diringkas pada tabel 4.9 menunjukkan bahwa nilai koefisien Capital Adequacy Ratio (CAR) bertanda negatif yang berarti bahwa CAR memiliki hubungan yang berlawanan arah dengan tingkat kesehatan bank. Hasil pengujian dengan Ordinal Logistic Regression juga menunjukkan bahwa CAR tidak memiliki pengaruh secara signifikan terhadap tingkat kesehatan bank. Hal ini tidak sesuai dengan teori yang menyatakan bahwa semakin besar modal maka dapat meningkatkan pendapatan bank sehingga keuntungan yang diperoleh juga

meningkat dan predikat kesehatan bank pun juga ikut naik. Berdasarkan hasil pengujian ini, CAR tidak memiliki pengaruh yang signifikan terhadap tingkat kesehatan bank. Hal ini mengindikasikan bahwa semakin besar modal yang diperoleh bank tidak selalu dapat meningkatkan pendapatan yang berdampak pada meningkatnya keuntungan dan predikat tingkat kesehatan yang diperoleh

suatu bank.

Pengaruh CAR yang negatif tidak signifikan dapat terjadi karena peningkatan profitabilitas turut diikuti pula oleh meningkatnya kebutuhan pembentukan cadangan dalam rangka mengantisipasi konsekuensi peningkatan risiko sejalan dengan optimalisasi produktivitas aset, sehingga kecukupan permodalan Bank Umum Syariah yang diproksikan dengan CAR mengalami penurunan (Dhian,2010). Selain itu, hal ini dapat dikarenakan bank umum syraiah belum secara signifikan memanfaatkan sumber- 
sumber tambahan modal lainnya sehingga pertumbuhan modal tidak dapat mengimbangi pertumbuhan aktiva produktif, yang seharusnya dapat menambah pendapatan yang berdampak pada tingkat kesehatan bank dan akan berdampak pada kemampuan bank untuk melakukan ekspansi penyaluran dana. Sehingga, pengaruh CAR dapat terjadi dengan nilai koefisien negatif dan tidak signifikan terhadap tingkat kesehatan bank.

\section{Pengaruh Non Performing Financing (NPF) Terhadap Tingkat Kesehatan Bank}

Hipotesis 2 : NPF berpengaruh terhadap tingkat kesehatan bank

Berdasarkan hasil pengujian dengan Ordinal Logistic Regression Regression yang diringkas pada tabel 4.9 menunjukkan bahwa nilai koefisien bertanda positif yang berarti bahwa NPF memiliki hubungan yang searah dengan tingkat kesehatan bank. Hasil pengujian dengan Ordinal Logistic Regression juga menunjukkan bahwa NPF memiliki pengaruh secara signifikan terhadap tingkat kesehatan bank. Hubungan NPF yang searah dengan tingkat kesehatan bank ini tidak sesuai dengan teori yang menyatakan bahwa semakin tinggi nilai NPF maka semakin buruk kualitas pembiayaan yang diberikan oleh bank yang menyebabkan jumlah kredit semakin besar dan turunnya keuntungan yang diperoleh.

Ketidaksesuaian dengan teori ini disebabkan karena tidak adanya sistem bunga dalam perbankan syariah dalam menjalankan aktivitasnya terutama dalam sistem pembiayaannya, sehingga perbankan syariah cenderung lebih kuat menghadapi gejolak moneter dan justru menjalankan fungsinya sebagai intermediary. Oleh karenanya, meskipun Non Performing Financing (NPF) menunjukkan nilai yang besar, Perbankan Syariah masih mampu menopang gejolak yang terjadi akibat pembiayaan bermasalah yang terjadi. Hal ini dikarenakan tidak ada sistem bunga dalam kegiatan operaional pembiayaannya.

\section{Pengaruh Beban Operasional dan Pendapatan Operasional (BOPO) Terhadap Tingkat Kesehatan Bank}

Hipotesis 3 : BOPO berpengaruh terhadap tingkat kesehatan bank

Berdasarkan hasil pengujian dengan Ordinal Logistic Regression yang diringkas pada tabel 4.9 menunjukkan bahwa nilai koefisien bertanda yang negatif berarti bahwa BOPO memiliki hubungan yang berlawanan arah dengan tingkat kesehatan bank. 
Hasil pengujian dengan Ordinal Logistic Regression juga menunjukkan bahwa BOPO memiliki pengaruh secara signifikan terhadap tingkat kesehatan bank. Hubungan BOPO dengan predikat tingkat kesehatan bank berlawanan arah karena peningkatan biaya operasional lebih besar daripada pendapatan operasional maka laba yang diperoleh bank akan mengalami penurunan sehingga predikat tingkat kesehatan bank pun akan menurun.

Kegiatan utama bank pada prinsipnya adalah bertindak sebagai perantara (intermediary), yaitu menghimpun dan menyalurkan dana, maka biaya dan pendapatan operasional bank didominasi oleh biaya pembiayaan dan hasil bagi hasil. Perusahaan dengan BOPO besar mencerminkan kurangnya kemampuan bank dalam menekan biaya operasionalnya yang dapat menimbulkan kerugian karena bank kurang efisien dalam mengelola usahanya.

\section{Pengaruh Return On Asset (ROA) Terhadap Tingkat Kesehatan Bank}

Hipotesis 4: ROA berpengaruh terhadap tingkat kesehatan bank

Berdasarkan hasil pengujian dengan Ordinal Logistic Regression yang diringkas pada tabel 4.9 menunjukkan bahwa nilai koefisien bertanda yang negatif berarti bahwa Return On Asset (ROA) memiliki hubungan yang berlawanan arah dengan tingkat kesehatan bank. Hasil pengujian dengan Ordinal Logistic Regression juga menunjukkan bahwa Return On Asset (ROA) tidak memiliki pengaruh secara signifikan terhadap tingkat kesehatan bank.

Penelitian ini tidak sesuai teori yang menyatakan bahwa ROA memiliki hubungan positif terhadap tingkat kesehatan bank. Hal ini berarti bahwa semakin besar rasio ROA menunjukkan bahwa bank memiliki kemampuan untuk meningkatkan pendapatan, sehingga kinérja bank dikatakan semakin

baik dan tingkat kesehatan bank pun ikut meningkat. Ketidaksesuaian hubungan ROA dengan tingkat kesehatan bank dengan teori dan nilai koefisien ROA yang bernilai negatif dapat terjadi karena terdapat profitabilitas yang digunakan untuk menutupi kegagalan pembiayaan yang lebih besar dibanding dengan laba yang diperoleh, sehingga hubungan ROA dengan tingkat kesehatan bank berlawanan arah. Hal ini juga dapat terjadi laba yang diperoleh bank tersebut digunakan untuk menutup 
beban-beban operasional yang digunakan untuk kegiatan operasionalnya termasuk kegiatan pembiayaan yang dilakukan oleh Bank Umum Syariah (Lina, 2007)

\section{Pengaruh Financing to Deposit Ratio (FDR) Terhadap Tingkat Kesehatan Bank}

Hipotesis 5 : FDR berpengaruh terhadap Tingkat kesehatan bank

Berdasarkan hasil pengujian dengan Ordinal Logistic Regression yang diringkas pada tabel 4.9 menunjukkan bahwa nilai koefisien bertanda yang negatif berarti bahwa Financing to Deposit Ratio (FDR) memiliki hubungan yang berlawanan arah dengan tingkat kesehatan bank. Hasil pengujian dengan

Ordinal Logistic Regression juga menunjukkan bahwa Financing to Deposit Ratio (FDR) tidak memiliki pengaruh secara signifikan terhadap tingkat kesehatan bank.

Hubungan Financing to Deposit Ratio (FDR) dengan tingkat kesehatan bank yang berlawanan arah mengindikasikan bahwa semakin tinggi rasio ini menunjukkan bahwa tingkat kesehatan bank menurun. Hal ini dapat terjadi karena jumlah pembiayaan yang diberikan besar dan dana yang dikeluarkan untuk pembiayaan tersebut juga akan meningkat. Peningkatan jumlah dana yang diperlukan juga akan akan menambah beban operasional yang dikeluarkan oleh bank. Akibatnya pendapatan yang seharusnya dapat menambah keuntungan harus dialihkan untuk menambah dana pembiayaan. Hal ini juga dapat diakibatkan karena jumlah gagalnya pembiayaan yang disalurkan sehingga laba yang diperoleh dari pembiayaan harus digunakan untuk menutupi kegagalan pembiayaan tersebut.

\section{KESIMPULAN}

Berdasarkan hasil pengujian, Capital Adequacy Ratio (CAR) tidak memiliki pengaruh secara signifikan dan memiliki hubungan berlawanan arah terhadap tingkat kesehatan bank. Perbankan syariah yang memiliki CAR tinggi maka akan semakin tinggi pula laba yang diperoleh. Namun, CAR yang terlalu tinggi menggambarkan bahwa banyak dana yang ada di perbankann syariah menganggur. Sehingga, kesempatan bank untuk mendapatkan laba akan menurun, akibatnya akan menurunkan profitabilitas bank yang akan berdampak pula terhadap tingkat kesehatan bank.

Berdasarkan hasil pengujian, Non Performing Financing (NPF) memiliki pengaruh secara signifikan dan memiliki 
hubungan searah terhadap tingkat kesehatan bank. Semakin tinggi rasio NPF menunjukkan bahwa bank tersebut tidak profesional dalam pengelolaan pembiayaannya sekaligus memberikan indikasi bahwa tingkat risiko atas pemberian pembiayaan pada bank tersebut cukup tinggi searah dengan tingginya NPF yang dihadapi bank.

Berdasarkan hasil pengujian, Beban Operasional Pendapatan Operasional (BOPO) memiliki pengaruh secara signifikan dan memiliki hubungan berlawanan arahterhadap tingkat kesehatan bank. Perbankan syariah yang memiliki BOPO rendah mengindikasikan bahwa semakin naik kinerja manajemen dalam mengelola sumber daya yang ada. Perbankan syariah dengan BOPO besar, mengindikasikan bahwa biaya operasional bank lebih besar dari pada pendapatan operasional. Hal ini akan berdampak pada laba yang diperoleh suatu bank. Laba yang diperoleh bank mengalami penurunan sehingga mempengaruhi tingkat profitabilitas yang berakibat pada menurunnya tingkat kesehatan bank.

Berdasarkan hasil pengujian, Return On Asset (ROA) tidak memiliki pengaruh secara signifikan dan memiliki hubungan yang berlawanan arah terhadap tingkat kesehatan bank.Jika suatu bank memiliki ROA tinggi berarti bank tersebut memiliki tingkat keuntungan yang tinggi pula. Semakin besar tingkat ROA suatu bank, semakin baik pula posisi bank tersebut dari segi penggunaan aset. Peningkatan keuntungan suatu bankyang tidak diikuti dengan pengefisienan biaya operasional, dapat mengakibatkan jumlah biaya operasional lebih besar dari jumlah keuntungan yang diperoleh. Sehingga, laba yang seharusnya dapat digunakan untuk meningkatkan profitabilitas, harus digunakan untuk menutupi biaya- biaya operasional. Hal ini akan berdampak pada menurunnya tingkat profitabilitas dan menurunnya tingkat kesehatan bank.

Berdasarkan hasil penelitian, Financing to Deposito Ratio (FDR) tidak memiliki pengaruh secara signifikan dan memiliki hubungan yang berlawanan arah terhadap tingkat kesehatan. Semakin tinggi rasio FDR, semakin rendah tingkat kesehatan bank. Menurunnya tingkat kesehatan bank dapat terjadi karena jumlah pembiayaan meningkat yang diikuti dengan besarnya jumlah kegagalan pembiayaan. Hal ini dapat mengakibatkan adanya kredit macet. Sehingga, bank harus mengeluarkan dana untuk mengatasi kredit macet tersebut. Keuntungan yang harusnya 
didapat atas meningkatnya pembiayaan harus disalihkan untuk membiayai kegagalan pembiayaan tersebut.

\section{SARAN}

Bagi investor, penelitian ini dapat dijadikan sabagai bahan masukan dan juga informasi bagi calon calon nasabah yang akan menggunakan jasa perbankan, khususnya perbankan syariah dalam menyimpan, meminjam maupun mendepositokan uangnya dengan mempertingkan kinerja dari

bank tersebut.

Bagi perusahaan perbankan syariah penelitian ini digunakan untuk dapat dijadikan referensi bahwa penting halnya mengetahui perkembangan tingkat kesehatan banknya. Sehingga selalu tercipta Good Corporate Governance dalam mejalankan setiap aktivitas yang berkaitan dengan perbankan. Bagi akademisi, penelitian ini digunakan untuk bahan masukan mengenai perkembangan perbankan serta menambah literatur dalam penelitian yang akan datang.

\section{REFERENSI}

Achmad,T. \& Kusumo,W.K.2003 . Analisis Rasio- Rasio Keuangan Sebagai Indikator Dalam Memprediksi Potensi Kebangkrutan Perbankan Di Indonesia. Media Ekonomi \& Bisnis, Vol.XV,No.1 (Juni)

Almilia dan Herdiningtyas.2005. Analisis Rasio Camel Terhadap Prediksi Kondisi Bermasalah Pada Lembaga Perbankan Periode 2000- 2002. Jurnal Akuntansi Dan Keuangan Vol.7 No.2 Stie Perbanas: Surabaya

Antonio, Muhammad Syafii. 2011.Bank Syariah : Dari Teori ke Praktek. Gema Insani Press bekerjasama dengan Yayasan Tazkia Cendekia.

Dendawijaya, Lukman.2005. Manajemen Perbankan.Ghalia Indonesia:Jakarta

Dewi,Dhika.2008.Faktor-Faktor Yang Mempengaruhi Profitabilitas Bank Syariah Di Indonesia. Artikel Jurnal

Dhian. 2010. Pengaruh CAR, BOPO, NPF dan FDR Terhadap Return On Asset (ROA) Bank Umum Syariah. Artikel Jurnal

Ghozali, Imam. 2012. Aplikasi Analisis Multivariate dengan Program IBM SPSS 20. Semarang: Badan Penerbit Universitas Diponegoro 
Iqbal, Zainur. 2011. Analisis Risiko Perbankan Syariah. Jakarta: Salemba Empat

Jacob, Jeremiah Kevin Dennis.2013.Analisis Laporan Keuangan Dengan Menggunakan Metode CAMEL Untuk Menilai Tingkat Kesehatan Perbankan.Jurnal EMBA,Vol.3 (September)

Kasmir. 2004. Manajemen Perbankan.Jakarta: PT Raja GrafindoPersada

Kuncoro, Mudrajat. Dkk. .2011. Manajemen Perbankan. BPFE: Jogjakarta.

Lestari dan Rahyuda. 2011.Analisis Penilaian Tingkat Kesehatan Bank Pada PT.Muamalat Syariah,Tbk Cabang Denpasar.Artikel Jurnal

Lina.2007. Pengaruh Kinerja Keuangan Terhadap Predikat Kesehatan Bank- Bank Umum Swasta Nasional. Rangkuman Skripsi. Surabaya: STIE Perbanas

Mahmud,dkk.2009.Bank Syariah, Teori ,Kebijakan, dan Studi Empiris Di Indonesia. Jakarta: Erlangga

Muhamad.2011.Bank Syariah, Analisis Kekuatan, Kelemahan Dan Ancaman.Yogyakarta: Ekonisia

Munawir, S. 2002 . Analisis Laporan Keuangan. Liberty :Yogjakarta.

Nusantara, Ahmad Buyung. 2009. Analisis Pengaruh NPL, CAR, LDR dan BOPO Terhadap Profitabilitas Bank. Tesis Program Pasca Sarjana Magister Manajemen Universitas Diponegoro. http:/empiris.undip.ac.id

Peraturan Bank Indonesia No.9/1/PBI/2007

Riyadi, Slamet.2006. Banking Asset Dan Liability Managemnet. Fakultas Ekonomi Universitas Indonesia: Jakarta

Riyanto, Bambang. 2011. Dasar-Dasar Pembelanjaan Perusahaan. Yogjakarta:BPFE

Ruwaida, Fitri.2011.Analisis Laporan Keuangan Untuk Menilai Tingkat Kesehatan Keuangan Pada PD BPR

Bank Klaten. Fakultas Ekonomi Universitas Negeri Yogjakarta: Yogjakarta

Septian, Dea.2013.Analisis Pengaruh Rasio CAMEL Terhadap Tingkat Kesehatan Bank Pada Bank Umum

Swasta Nasional Di Indonesia Periode 2007- 2011. UIN Syarif Hidayatullah Jakarta: Jakarta 
Siamat,Dahlan.2005.Manajemen Lembaga Keuangan. Jakarta: Fakultas Ekonomi Universitas Indonesia

Sugiarti, Welthi.2012.Analisis Kinerja Keuangan Dan Prediksi Tingkat Kesehatan Bank Dengan Menggunakan Metode CAMEL Pada Bank Umum Yang Tercatat Di Bursa Efek Indonesia.Fakultas Ekonomi :Universitas Gunadarma.

Sugiyanto,FX.,Prasetiono,Hariyanto,T.2002.Manfaat IndikatorIndikator Keuangan Dalam Pembentukan

Model Prediksi Kondisi Kesehatan Perbankan.Jurnal Bisnis Strategi,Vol.10 (Desember)

Surat Edaran Bank Indonesia No.6/23/DPNP tahun 2004

Taswan.2006. Manajemen Perbankan. Yogjakarta: UPP STIM YKPN

Theresia dan Mutia Ismail.2009."Pengaruh Hutang Terhadap Laba Usaha Pada Perusahan Barang Konsumsi Yang terdaftar Di Bursa Efek Indonesia". Jurnal Akuntansi 18

Triandaru, Sigit dan Budisantoso, Totok.2006. Bank Dan Lembaga Keuangan Lain Edisi II. Salemba Empat: Jakarta.

Utama dan Mahadewi. 2012.Analisis CAMELS: Penilaian Tingkat Kesehatan Bank Yang Terdaftar Di Bursa Efek Indonesia. www.bi.go.id

Jurnal Bisnis dan Kewirausahaan,Vol.8 (Juli) 